\title{
Religion in Indonesia's Elections: An Implementation of a Populist Strategy?*
}

\author{
Rizky Widian (D), Putu Agung Nara Indra Prima Satya (D) and Sylvia Yazid \\ International Relations Department, Parahyangan Catholic University, Bandung, Indonesia \\ Corresponding author: Sylvia Yazid, E-mail: s_yazid@unpar.ac.id
}

(Received 16 April 2020; revised 29 July 2021; accepted 5 August 2021)

\begin{abstract}
In Indonesia's political strategic environment, Islamic narratives have been among the main narratives, but have not always been dominant. The 2014 presidential election displayed the beginning of a rising trend of Islamic narratives within the political context in Indonesia. Since then Islamic narratives influenced the strategy of Indonesia's populist leaders, as particularly seen during the 2017 Jakarta gubernatorial election and 2019 presidential election. This paper analyzes how populism as a strategy was used in recent Indonesian elections. For this purpose, it uses the conception of populism as a political strategy proposed by Weyland. Building on this approach, the paper explains the strategic adjustments made in the use of populism from 2014, 2017, and 2019 in Indonesian political events. It argues that the strategic environment faced by populist actors in Indonesia's 2019 election affected their decision to choose Islamic narratives as an instrument for mass mobilization.
\end{abstract}

\section{Introduction}

As the world's third largest democracy, many scholars have put attentive eyes toward how the global populism upsurge will unfold in Indonesia. Although the concept of populism has yet to find a systematic definition due to its complexity, different approaches have been made in an attempt to depict the phenomenon-from ideational, structural political economy to political strategy. There have been a number of debates on applying the right label to Indonesian populism, especially with the recent headline-grabbing presidential election that put Joko Widodo "Jokowi" and Prabowo Subianto on the stage. The former, an "outsider" who is neither part of any established political dynasty nor an oligarch, started as a modest city mayor of

* The research for this paper was made possible by the funding from the Fritz Thyssen Foundation. The authors would like to express our gratitude to Matthias Kortmann, Christopher Beuter and TU Dortmund team for the opportunity and academic collaboration. We also would like to acknowledge the assistance of Cheryl Michelin Pangestu in the data gathering and writing process of this paper.

(C) The Author(s), 2022. Published by Cambridge University Press on behalf of Religion and Politics Section of the American Political Science Association. This is an Open Access article, distributed under the terms of the Creative Commons Attribution licence (http://creativecommons.org/licenses/by/4.0/), which permits unrestricted re-use, distribution, and reproduction in any medium, provided the original work is properly cited. 
Solo and has been popular for being a breath of fresh air in the oligarchic Indonesian political system. The latter is portrayed through his profile as former military general and son-in-law of the former authoritarian president Suharto.

Using a political economy approach, Vedi Hadiz uses the term Islamic Populism to describe Indonesia's populism and categorizes both Jokowi and Prabowo as populists (Hadiz 2016). When populism is examined using a structural political economy approach, it is argued that there is a close relation between populist politics and socioeconomic conditions. The "us vs. them"-rhetoric revolves around divisions of class or economic attributes. Oxhorn, for example, argues that populism depends upon social inequality and heterogeneity in society (Oxhorn 1998). From this perspective, populism seems to be focused on gathering support from poorer voters who expect the political leader to be working against rich and corrupt elites. In this discussion, Weyland, through the case study of Latin America, argues that in the 1980s and 1990s some populist political tactics used neoliberal reform that diverged radically from economic populism which has been usually attached to "leftist" economic programs or policies (Weyland 2001, 4). Furthermore, in the case of contemporary Indonesia, Fossati found that populist sentiments in Indonesia are not entirely stemming from economic circumstances and frustrations (Fossati 2019, 782). Therefore, there is still room to argue that comprehensively understanding Indonesia's populism requires more than a political economy analysis.

The other alternative is to use the ideational approach as reflected in Cas Mudde's definition of populism, "an ideology that considers society to be ultimately separated into two homogeneous and antagonistic groups, 'the pure people' versus 'the corrupt elite,' and which argues that politics should be an expression of the volonté générale (general will) of the people" (Mudde 2004, 543). The ideology mentioned in Mudde's definition refers to what is known as a "thin-centered" ideology (Stanley 2018). In the case of Indonesia, among the scholars that use this perspective are Kyle and Gultchin that label Jokowi as an anti-establishment populist (Kyle and Gultchin 2018). Another example is Hatherell who argues that only Prabowo fits the populist characteristic by dichotomizing Indonesian society into two homogenous groups, pure Indonesian and evil foreign entities (Chinese investors, kafir-heathens, non-Muslims), while Jokowi did not fulfill the characteristics by being a technocrat who focuses on development programs instead (Hatherell and Welsh 2019, 4). Furthermore, Mietzner also used this perspective and has clearly explained how populism as a thin-centered ideology is relevant to explain the context of Indonesia (Mietzner 2020). Nevertheless, although the ideational perspective is useful to explain ideological factors in populism, it is still not sufficient to explain how the exploitation of ideology is used as a vote-gathering strategy to seize political power. Furthermore, according to Fossati, the ideational definition of Mudde does not discuss the actors that use the thin centered ideology (Fossati 2019, 773). That is how the ideology itself as an important aspect of the strategic environment has been capitalized by a populist leader.

This is not to say that the definition of populism as a thin-centered ideology is contradictory to the strategic point of view. In this case, Mietzner acknowledges that the strategic point of view does not contradict Mudde's definition of populism (Mietzner 2020, 3), which is also stated by Fossati in a similar manner (Fossati 2019, 773). In fact, they understand the two approaches as two sides of the same 
coin and utilize the strategic point of view to describe who the populist leaders in Indonesia are. However, the way the populist leader capitalizes on populism, how their strategy changes through the changing strategic environment and how this strategic environment affects the populist rational choice are yet to be explored comprehensively. Thus, this paper intends to contribute to the growing discussion about populism in Indonesia, by answering these questions-an addition to the political strategy approach-which we deem necessary in comprehending the rationales behind the actors' actions, particularly in relation to their strategy changes.

In the case of Indonesia, Islam has been a significant aspect of its political strategic environment. The Islamic narratives itself may not always be dominant but it is never entirely absent, waiting for the right time to surface. The political event of the 2014 presidential election has started the upsurge trend of the use of Islamic narratives as political tools. This trend has influenced the populist leaders' choice of strategy in the 2017 Jakarta gubernatorial election and 2019 presidential election. Therefore, our analysis of the practice of populism in Indonesia's political sphere takes into account the newly defined approach of Islamism and Indonesia's already established ideological basis of Pancasila with a relatively low involvement of political parties in Indonesia. This includes the role of informal political bodies/mass organizations that have created a certain political momentum to activate the mobilization of Islamic-based populism in Indonesia.

This paper argues that the strategic environment faced by populist actors in Indonesia's 2019 election influences their decision to choose Islamic religious narratives as an instrument for mass mobilization, as a result of strategic considerations. It also shows how the use of religious narratives in politics is often a result of identity entrepreneurship, that is, a political strategy used by politicians as a result of a rational choice. Through understanding the populist leaders' strategy and how their strategy changes, it can be explained how populism could be attached to certain identity narratives (or big ideology in the ideational perspective) according to strategic needs. These strategic needs are influenced by the surrounding strategic environment that is closely related to the electoral market. Although the importance of strategic environment has been discussed in many political and policy studies, the case of Indonesia's recent political contestation highlights how the strategic environment could significantly motivate the populist actors to "adjust" their identities to fit the strategic environment while at the same time molding the strategic environment to fit their objectives, an act which we see as an act of identity entrepreneurship in a highly dynamic political context.

The analysis of this paper focuses on the major political actors and figures who took the initiative and, later, advantages, through the use of identity and religious narratives as a major vote-generating factor in Indonesian politics. The argument of this paper is that Indonesian political figures have an arguably flexible political imagery due to the use of populism and specific political rhetoric in communicating with their targeted voters. To put the argument into context, this paper elaborates on three political momentums, namely the 2014 presidential election, the 2017 Jakarta gubernatorial election, and the latest 2019 presidential election to explore the political strategic environment and highlight the growing trend and unique features of Indonesian populism. 
In order to get a clear picture of the political context of the elections, we apply qualitative methodology to gather data from sources such as mass media, political speeches, and other related literature. Through a deductive approach of qualitative methodology, the theoretical perspective in this paper will be used as a guideline to analyze collected data (Neuman 2003, 451). The next section will briefly describe the conceptual approach of political strategy before we contextualize the development and traces of populism in Indonesia to deliver a more comprehensive background for the analysis.

\section{Populism as Political Strategy}

This paper understands populism in Indonesia as part of a political strategy especially to gain votes and mobilize the people through a specific political momentum. Although this paper acknowledges the compatibility between strategic and ideational approaches, this paper utilizes a strategic approach to explore the changes of political strategic environments in Indonesia and how they affect rational choices of the populist leaders in implementing their vote-gathering strategy. This paper uses the conception of political strategy in analyzing populism to explain the strategic adjustments made in the use of populism from 2014, 2017, and 2019 in Indonesian political events. Because of this focus on political strategy, this paper argues that Indonesia's populism resembles Kurt Weyland's definition of populism: “... a political strategy through which a personalistic leader seeks or exercises government power based on direct, unmediated, un-institutionalized support from large numbers of mostly unorganized followers." He also emphasizes that populist leaders usually have opportunistic and flexible characteristics, which means that they are usually not attached or do not commit themselves completely to the ideas that they present to society (Weyland 2001, 11). The flexibility and opportunistic nature of populist leaders enable them to use pragmatic strategies that they see fit to gather more support or votes from the masses (Weyland 2001, 10-18). In this regard, Weyland gives an example and argues that even right-wing political actors sometimes win significant vote shares if they water down their ideological commitments and turn into flexible vote-getters (Weyland 2017, 67). In other words, the political strategy perspective defines populism as a strategy that can use various forms of ideas as instruments to help win more votes in political contestation.

Weyland's definition includes the terms "unorganized followers" and "direct, unmediated, un-institutionalized support." In this context, Weyland elaborates that personalized leadership bypasses formal political institutions in mobilizing the masses and creating the intermediary organization in order to bridge the gap between leader and mass. This condition usually appears when people have not believed in formal political institutions or in what Cas Mudde calls "the corrupt elites." Nevertheless, populism as a political strategy still needs concrete methods to work in the political arena, and to serve the needs of winning and exercising power. Populist leaders must ensure that they can secure the core of populist goals, broad mass support (Weyland 2001). Thus, populist leaders must answer the main question: what is the main strategy to transform the "unorganized followers" into "broad mass support"? And when the leader already obtained this "broad mass support," will it automatically translate into votes? 
The issue of creating broad mass support and, thus, gaining concrete votes, can be illustrated with the historical institutionalist approach. This approach structures political strategy into two parts, structure and agency, along with the dynamics between them. Agency refers to the political actor such as leaders and political parties and structure refers to the environment and the context surrounding the agency. As laid out by Olli Hellmann, the relations between structure and agency can be described as follows: "Agents are able to develop different strategic responses to the same structural context, while, at the same time, the structural context is strategically selective, favoring certain strategies over others," (Helmann 2011, 7). In this light, we see party organizations and political strategies as "...strategic responses to the context in which political actors find themselves” (Helmann 2011, 8).

The main operational arena of political strategies is the electoral system. To survive and gain benefits in this arena, political actors need to interpret the context/strategic environment. Actors' ability to interpret the strategic environment depends on their resources and their set of ideas in utilizing the opportunities in the strategic environment itself. Furthermore, political actors should also consider the "electoral markets" that may be suitable for some strategies but unfavorable to others (Helmann 2011, 15-16). In sum, the benefit of electoral systems can only be gained by connecting the right resources with the potential voters in the suitable political context, which will be explored for the Indonesian context in this paper.

One of the most prominent strategic environments in Indonesia centers around the social identities that exist within society. Contemporary Indonesian politics are still facing the transition process toward a more democratic condition after the fall of Suharto's dictatorship back in 1998. In this situation, the democratic institutions, such as political parties, parliament, and elections, are still lagging behind in conducting their ideal tasks. Facing these kinds of obstacles, leaders planning to join elections need a strategy to bypass these institutional problems and directly mobilize the masses who have low levels of trust toward politicians. In most cases, populist leaders choose social identity and a primordial approach to get into the potential voters' preferences.

Stephen Reicher et al. argue that social identity transforms the relationship between people in such a way as to enable coordinated and effective collective action (Reicher et al. 2005, 624). Social identity puts the people together into the same social category, thus creating trust, respect, solidarity, and agreement among them. In other words, when people share the same identity and hence the same values and goals, it opens a chance for somebody (or an institution) to represent what they have in common. This is a strong foundation for achieving widely accepted leadership in a specific society.

The flexible opportunistic characteristics of the populist leader and how they capitalize their surrounding strategic environment are closely related with a concept known as identity entrepreneurship. Reicher and Haslam define entrepreneurs of identity as "...the ability of the would-be leader to represent himself and his platforms in ways that make them articulate with the ways in which his would-be followers experience their world hence render himself representative of this world" (Reicher and Haslam 2017, 34). In other words, identity entrepreneurship of political leaders is closely related to the leader's rhetorical ability to construct social categories that 
affirm their own leadership credentials (Haslam 2007, 127). To have more influence and be effective, leaders need to represent themselves as a "prototypical" of the social identity in question. These criteria of identity entrepreneurship, as we will explain in more detail later, reflect the behavior of populist leaders in Indonesia's 2019 presidential election, who framed themselves as prototypes of a certain mass identity to gather more support. Drawing on these conceptual considerations, the paper will, in the following, analyze how the strategic environment changed and influenced political actors' strategies in recent elections, in how far they display Weyland's characteristics of populist strategy, and in how far identity and identity entrepreneurship become part of these strategies.

\section{Revisiting Traces of Populism in Indonesia: Reconciling Pancasila and Islam in Political Strategy}

Before discussing the election context, we need to identify the traces of populism in Indonesia. Populist traces in Indonesia date back to colonial times, when the fights for independence were strongly linked to identity-based narratives that were used to mobilize mass movements, up to the present electoral politics. In this regard, this section will elaborate how Pancasila as the main identity narrative is coupled with Islam in Indonesian politics and nation-building as part of the ideational and also strategic environment of this country's populism tendency. Assuming that populism is a "thincentered ideology" that should attach itself to a more established and widely accepted ideologies, we argue that Pancasila and Islam are the ideal "attachment" for the Indonesian political arena. On the contrary, the mixture between Pancasila and Islam in Indonesia is a must since Islam could not form a significant political discourse by itself as it did in Islamic countries such as Turkey or countries of the Middle East. Indeed, Islam is a majority religion and a strong identity dimension that influenced Indonesian politics. Nevertheless, Indonesia is still a pluralistic state by its constitution. Therefore, the Islamic discourse must adapt with the fact that Pancasila - which has the plurality value at its core-is still the primary ideology in Indonesia.

In this regard, we should comprehend the position of 'Pancasila' as the only definitive and legitimate state ideology in Indonesia. Pancasila consists of five main principles: belief in one Almighty God, just and civilized humanity, unity of Indonesia, democracy guided by the inner wisdom of the deliberation of representatives, and social justice for all Indonesians. These concepts were later glorified and "holy-fied" by its founder, Soekarno, the first Indonesian president, as a guidance in this country's nation-building process. Soekarno defined Pancasila both as a founding self (philosofische groundslag) and the world view (Weltanschauung) of the nation and the state of Indonesia (de Marques 2019, 33). In short, Pancasila defines the national character by determining what it takes and what is meant to be a "good Indonesian citizen" and how to be a part of "Indonesian society" as a whole.

In the context of populism as a strategy to create a "prototypical leader," we argue that Pancasila is an ideational guideline that creates the "prototype variables" for the favorable figures of Indonesian leaders. In short, the good (and politically electable) 
leader of Indonesia must adhere to the values of Pancasila itself, i.e., be faithful to the Almighty God, have a good sense of humanity, be always ready to protect the unity of Indonesia, respect the democratic system, and fight for social equality within Indonesian society. The absence of one factor will make those leaders seem unsuitable for the job as we will see in the cases of the Indonesian election discussed later.

The domination of Pancasila as the main discourse in statehood and nationhood in Indonesia makes every political actor appear compatible with it, whatever their ideological basis might be. In fact, Pancasila can be used by different political actors to assert their demands. Vedi R. Hadiz describes this situation in the context of political transition after the fall of Suharto's dictatorship in 1998. At that time, no opposition group dared to attempt to re-appropriate Pancasila from the state (Hadiz 2004, 148), even when they knew that Suharto's Pancasila was the main legitimation for his dictatorship. Meanwhile, opposition groups such as the leftist labor movement cited Pancasila-especially the social justice part-to contest the inequality in Suharto's economic plan. At the same time, the liberal reformist opponent of Suharto's regime also used Pancasila to offer their agenda of economic liberalism based on free market principles (Hadiz 2004, 148).

Recently, even the radical Islamist activists bring Pancasila into their campaign and statements. For example, Rizieq Shihab from the Islamic Defenders Front often underlines the importance of sharia principles to protect Pancasila from communist threats (Kumparan 2019). He also demanded Pancasila to be defined as its "original" text in the Jakarta Charter (the first draft of the Indonesian constitution) that gave freedom to enact sharia law for Moslem communities in Indonesia (IPAC Report 2019, 8-9). Based on these facts, we can argue that Pancasila is "the only game in town" which political actors must build their populist strategy on. By this means, any later adoption of strategy, including in this case Islamic populism, is never meant to replace Pancasila but rather to gain legitimacy from it. Thus, it is clear that Pancasila remains the sole official state ideology of Indonesia.

Furthermore, the nuance of pluralism and multiculturalism in Pancasila also played an important role in the nation's first presidency under Sukarno, with nation-building tasks at hand which subsequently spared him a position with minimum restraints for a strong presidency (Hadiz and Robison 2017, 488-502). Portrayed as a strong and charismatic leader, Sukarno focused his oratory speeches with populist and anti-imperialist rhetoric to build unity and strong nationalism among post-colonial Indonesian society. With this, he had managed to build a cult around his leadership by depicting himself as the "tongue" of the people, promoting diversity and national belonging with Pancasila as the basis of his rhetoric. His populist style became an important base for Indonesian populism and managed to leave a trail in later Indonesian prominent political figures of the post-Suharto authoritarian era.

Even when Sukarno's downfall and replacement by Major General Suharto in 1966 had focused on its authoritarian and militaristic agendas, populism was utilized as a framework to legitimize Suharto's authority amid state-orchestrated elections and a tamed parliament as well as mass-based organizations that acted as cheerleaders of the state (Ziv 2001). The following presidencies in Reformasi-the reformed postauthoritarian system after the Suharto regime-was no different in terms of the utilization of populism, as Megawati Sukarnoputri, Sukarno's daughter, inherited and 
resurrected her father's populist rhetoric that emphasized national integrity to strengthen her oppositional stance on Suharto's regime (Ziv 2001). These strategies managed to produce a broad-based appeal and to form a larger cult of followers. Furthermore, Susilo Bambang Yudhoyono (SBY), her successor, was nothing less than a populist politician, presenting himself as the hero who stabilized democracy. SBY heavily subsidized the people's oil consumption to suppress the elitist image he carried. The consistent presence of populism within the regimes mentioned above, shows how ideology is embedded and has constantly evolved overtime to mobilize support the way politicians see fit.

Furthermore, after we understand the Pancasila's position and role, we also need to take a look at Islam as one of the strongest identity dimensions in Indonesian politics. Being the religion of the majority, Islam and its institutions had played a pivotal role in the anti-colonial fight (Zarkasyi 2008). One of the earliest notable examples is the establishment of Syarikat Islam in early 1920 that mostly served as a trading organization for Muslim entrepreneurs, which signified early attempts on social identitybased mobilization. Other examples include Muhammadiyah, an organization established in 1912 to assert reformist or "modern" Islamic ideals through education and welfare services, and its competitor, Nahdlatul Ulama, established in 1926 to fight for the maintenance of traditional Islamic values (Zarkasyi 2008). These two organizations were later involved in the formation of Masyumi, an Islamic political party which had dominated the ministerial cabinet and the elections in the early era of Indonesian independence (Zarkasyi 2008). The party tried to be inclusive with all spectrums of Indonesian Muslims to widen its voter-base, correlating Islamic values with nationalist agendas as its mobilization strategy (Madinier 2015). These examples show that Islam in Indonesia has had multiple spectrums, visions, and goals in its mobilization strategies, but all of them had aimed to dominate the political channel of the pluralist country.

Besides these attempts in the formal political channel, there have also been cases of hardliners: Muslims that tried to insert their religious-based interest in a more militant and clandestine way. One notable example is Darul Islam (literally translated as Islamic State) that aimed to include sharia law in the formulation of Pancasila which was later rejected due to Indonesia's pluralist background (Alamsyah and Hadiz 2017). This movement catered to Muslims with radically conservative views who thought that a lack of Islamic values in Indonesia's fundaments would lead the country to mismanagement, immorality, and eventual collapse. Although eventually defeated, the spirit of realizing an Islamic state with an Islam-based constitution lived through the course of Indonesian history, creating one similar rebellion after another, such as the Free Aceh Movement (GAM), Komando Jihad (Command of Jihad), etc. These cases show that mass-mobilization in covert ways, using identity as its instrument, existed in the Indonesian political realm, and is noteworthy for its distinct strategy in comparison with the ones in the formal political channel.

The strong identity narratives of these movements suggest two important contexts: first, as a country with a Muslim-majority, the dissatisfaction of Indonesian Muslims toward the non-Islamic constitution or at least toward the political channel specialized for Muslims' interests have existed before and continue to persist. Second, pluralism has always been the counterargument for this vision and served as the central 
identity for Indonesia that materialized into the national principle of Pancasila, five main principles for post-independence Indonesia in the spirit of unity and pluralism.

Thus, it is clear that Islam has deep roots in Indonesian political lives and history. In this regard, it is also clear that the rise of Islam as a dominant political discourse itself is not a new trend. In other words, the history of Islam in Indonesia is projected and to some extend affects the recent context of Indonesian developing democracy that has been marked by a growing narrative of intolerance by Islamic conservatives. In this case, it can be argued that among the most likely triggers of Indonesia's recent populist upsurge, are the movements by non-state actors such as FPI (Front Pembela Islam) and GNPF Ulama (Gerakan Nasional Pengawal Fatwa Ulama) that initiated the trend in mobilizing huge masses in this predominantly Muslim country. Politicians were then encouraged to cater to this market as it is strategically appealing to gather votes and support. This was later translated into a campaign strategy, forming a new pattern of populism that is entrenched with Islamic narratives.

In relation to the populist narrative upsurge in Indonesian politics, it has been argued that there has been a decrease in democracy building in Indonesia which Eve Warburton and Edward Aspinall called a "democratic regression" marked by "...the rise of a xenophobic brand of populist politics, an illiberal drift in the regulation of civil liberties and protection of human rights, and the government's manipulation of state institutions to entrench itself in power" (Warburton and Aspinall 2019, 256). Furthermore, it is noticeable that there are contradictions within Indonesian society in portraying democracy in Indonesia. Although public support for democracy as an abstract concept remains high, it does not extend to the institutions and values that underpin a liberal democratic order (Warburton and Aspinall 2019, 257). In their analysis, Warburton and Aspinall argue that the gap between these two poles has created so called "illiberal sensibilities" and provided the momentum for populist penetration in the democratic process in Indonesia.

Furthermore, Dirk Tomsa underlines the failure of political parties to fulfill their roles in the Indonesian democratic system as one of the factors behind the rise of populism. He stated that the parties in Indonesia rarely took the initiative to formulate comprehensive long-term visions for specific policy and preferred to respond to emerging policies or issues debated in society (Dirk Tomsa 2018, 102). They tend to transfer the initiative to mold political narratives to other non-partisan actors, such as civil society organizations, volunteers, and, of course, to presidential and regional elections (Pilkada) candidates (Dirk Tomsa 2018, 102). In this situation, patronage and clientelism with the existence of political brokerage, and created distrust from the masses about the goodwill of politicians, which consequently motivated the masses to distance themselves from the impurity of the political system, especially the parliament and political parties (Warburton and Aspinall 2019). Thus, it is clear that recent developments in Indonesian politics have witnessed populist narrative upsurges. In this case, the narratives are closely related to the role of conservative Islam as one of the determining factors in Indonesian political discourse.

Nevertheless, despite the inclination of conservative Islam in Indonesia, it still needs to reconcile with Pancasila as the dominant discourse. Those who dare to challenge the position of Pancasila as state ideology, will face exclusion from the political system, or worse, be accused as "enemy of the state." The disbanding 
of Hizbut Tahrir Indonesia (HTI) - a branch of a transnational radical but nonviolent Islamic group-by President Jokowi is a perfect example for this. After their involvement in a rally against the Christian Jakarta Governor Basuki Tjahaja Purnama, HTI was disbanded by Jokowi who issued a Regulation in Lieu of Law (Peraturan Pemerintah Pengganti Undang Undang/Perppu) that allowed the government to disband any organization which posed a threat to Pancasila. In fact, the government already had the means of banning such groups: the 2013 Law on Societal Organization prohibited organizations from "holding, promoting, as well as disseminating teachings or concepts which contradict Pancasila" (Warburton and Aspinall 2019, 261). In short, Islam as an ideational side of populism in Indonesia still needs Pancasila in its strategy. This creates a unique mixture between both, which can be translated into an effective political campaign.

\section{Populism in Indonesia: Flexible Politicians and the Use of Religion in A Dynamic Environment}

Analysis of the use of religious notions as a populist strategy in Indonesia will be based on the country's most recent political momentums: the 2014 presidential election, the 2017 Jakarta gubernatorial election, and the 2019 presidential election. The segmentation is intended to show the changing strategic environment along the 2014-2019 timeline. The analysis will focus on the use of religious notions through 2014 and 2017 which shaped the strategic environment for populist leaders in 2019. The strategic environment in this context is closely related to the movements of Islamic conservative organizations. These Islamic conservative groups led the infamous " 212 Action" which pushed the discourse of Islamism to a whole new level of mobilization of power and discourse in Indonesian politics. In addition, they were able to shape the political momentum in Indonesia and encouraged traditional political forces, including political leaders, to adjust their strategies in this strategic environment. Thus, the analysis in this section highlights the opportunistic and flexible characteristics of the political leaders who took advantage of the aforementioned strategic environment to show the dynamic nature of Indonesian populism.

In this case, we intend to argue that in the context of the 2014 and 2019 presidential elections, both Jokowi and Prabowo are populist. Some literature suggests that Jokowi is best described as a technocrat, rather than a purely populist leader. Hatherell and Welsh build this argument by underlining the fact that Jokowi rarely used the "us vs. them" rhetoric when defining the constituencies to gain sympathy from targeted voters. However, Mietzner finds that the narratives of "the pure people/good citizens" and the corrupt elite of Jokowi lie in the attempt to create a frame that he is part of the ordinary people (Mietzner 2020, 8). Jokowi also used a "popular" approach blusukan ${ }^{1}$ hat strengthened the framing that he represents the volonté générale of the people. Nevertheless, Jokowi's populism intensity is not as high as Prabowo's. This applies especially in the context of the robust use of religious narratives in the election. The following section explains the characteristics and strategies of the populist leaders and how religious narratives have been used as part of populist strategy. 
The 2014 Presidential Election and the Early Use of Religious Notions as Strategy

During the 2014 election, when he had his first run-off as presidential candidate, Prabowo grabbed Indonesia's attention with textbook populism, partly due to the fact that he used the same campaign advisor as Donald Trump, Rob Allyn. Prabowo addressed the political condition as broken and beyond repair, attacked foreign companies for extracting Indonesia's natural wealth without proper compensation, and told people that they should not put faith in the then ruling elites as they were all cronies of foreign parasites (Ostwald et al. 2018). Aiming for the rural and poor, Prabowo's populism also integrated Islamic rhetoric. This indicated his premature use of Islamic narratives as one of his campaign instruments, not yet central although, to strengthen the societal empathy, especially that of conservatives, as this particular group had fears of disorder and shifts away from Islamic values (Ristianto 2019). It is quite possible that Prabowo started to use the religious identity card because of the minimum depiction of religiosity adhered to by his competitor, Jokowi. Jokowi seemed more distant from Islam as his closest ally that brought both of them to fame was Ahok, a Christian Chinese Indonesian.

The 2014 election was the early manifesto of the trend to fill discourse with attacks and antagonizing of political opponents on the issue of identity which is supposed to be a sensitive issue in the pluralist Indonesian political context. During this period, prominent public figures such as ulamas or celebrities stated their disapproval of Jokowi for narratives such as that his mother was a Christian and therefore a kafir (literally translated as heathens) - a vague information that lacked proof yet was widely spread to their followers (IPAC Report 2019). This type of discourse would sustain and play an even more prominent role in the 2019 election. Furthermore, inequality, particularly economic inequality, has been a central issue in Prabowo's 2014 campaign. He explicitly blamed elites for the suffering of the middle class, hence, "othering" one particular group to earn his constituents' support (Muhtadi 2019, 46). Religious notions have not been used in a significant way in this case. This is not to say that Jokowi is not a populist. During his campaign in 2014 he stated that he will not be bound to the "elites" if he gets elected (Mietzner 2020, 9), making cautious use of "othering," stressing that he is not part of the current elites in Indonesian politics.

Even though the use of religious ideas as political instruments was yet to be significant, it is important to note the 2014 presidential election as the period during which earlier use of populist rhetoric can be noticed which would then continue to be used in the following political momentums in Indonesia. Its failures or successes in mobilizing masses had become a paramount lesson for those who reaped the benefits of the strategy.

\section{Populist Strategy in the 2017 Jakarta Gubernatorial Election}

The 2017 Jakarta gubernatorial election has a significant role in shaping the strategic environment of the Indonesian national electoral market in 2019. Although the election was only a regional-scale political momentum, as the capital of Indonesia, Jakarta's politics have been known to be one of the detrimental factors for those who want to advance to the national level (i.e., to become a presidential candidate). 
As the incumbent who represented a double minority and popular for his achievement in urban development, Ahok led in the early polls. Meanwhile, his competitors were Agus Harimurti Yudhoyono, a former military officer and the son of Susilo Bambang Yudhoyono (the sixth Indonesian president) and Anies Baswedan who had served as the Minister for Culture and Education in Jokowi's first cabinet with a notable track record in education and politics. After two rounds of election, Anies and Sandiaga Uno managed to secure a victory of $58 \%$ of the votes, making Anies the elected governor of Jakarta for the following 5 years (Setijadi 2017).

Anies' landslide victory was a surprise to many polling organizations, as they had predicted that the election was going to be a very tight race between Anies and Ahok. Regardless, the victory was acknowledged to be influenced by hardliner Muslim groups that strongly declared their support for Anies Baswedan, against the incumbent who was labeled as "kafir." Hence, the election was seen as a major starting point for the conservative turn of Indonesian Muslims, creating a much more obvious segregation between Muslims and non-Muslims. Despite being known as a moderate Muslim figure, Anies did not object to being related to the conservative side of the spectrum (Mufrodi 2017). We would argue that this is a strategy used after considering the polarized social condition of the Jakarta electorate at the time of the election, due to the accusation of religious blasphemy toward Ahok, known as the Al-Maida 51 case.

The Al-Maida case was triggered by one of Ahok's statements that quoted a verse of Qur'an which was then framed as a blasphemous act and the North Jakarta High Court found Ahok guilty on these charges (Setijadi 2017). The widespread politicization was utilized by Ahok's political opponents, specifically organizations such as Front Pembela Islam (FPI) to spark anger which significantly impacted Ahok's electability by the time of election. For Ahok, the Al-Maida case worsened the already wavering electability rate, stripping away some of his supporters' votes from the 2012 election when he became a candidate for vice-governor with Jokowi (Muhtadi 2019, 18-22). The political effect of the blasphemy case was not the ultimate factor of Ahok's loss, since failure is more likely than not to be caused by a multitude of factors. Nonetheless, we will present the arguments below to explain two important points: the factors behind the social movements' success in utilizing the populist rhetoric in the 2017 election and the implications for the Islamic social movements in Indonesia.

Hardliner Muslim groups such as FPI had expressed their rejection toward having a non-Islamic leader since 2012, when Ahok first took office. Refusal to vote for Ahok for identity-based reasons also existed among a significant portion of Jakartans which can be observed through the poll conducted by Indikator Politik in June 2016. In total, $27.1 \%$ of voters claimed that they were satisfied with Ahok's performance as the governor but would not vote for him, where $72 \%$ of this segment also agreed to the statement that "a leader has to be the same religion as me" (Setijadi 2017). These data indicate that although Muslim Indonesians come from different and broad spectrums-moderate to conservative-of Islamic teachings, there are traces of the influence of religious values in their considerations in the voting booth. Another poll was also able to show that although Ahok still had 70-75\% of approval ratings with regard to his achievements as Jakarta governor by the time the blasphemy issue emerged (Muhtadi 2019, 52), his loss in the election strengthened the notion that electorates' rationale did not prioritize rational and pragmatic choices. 
The election later evolved into primarily religious-based issues. This is to say, that although Jakarta electorates recognized Ahok's capability in developing and leading the region, at the end of the day, his (non-Muslim) identity became a more decisive influence on their choice.

Muhtadi argues that the modality of identity politics in the case of Al-Maida 51 has been the main engine behind Anies' victory (Muhtadi 2019, 21). Furthermore, the head DPP of PKS (Partai Keadilan Sejahtera/Prosperous Justice Party), Mardani Ali Sera admitted that he and his party took advantage of 212 movements to make Anies-Sandi, Ahok's competitors, win the gubernatorial election (Agung 2018). Ahok's competitors realized the strategic environment in Jakarta at that time and capitalized on it so they could mobilize the popular voices, embodied in mass movements, to achieve their goal to win the election. Conclusively, the 2017 election has strengthened the notion for the Islamic movements to have a say in the political arena. The 2017 election shows the effective use of religious narratives and its potential for future use in other political momentums.

After the 2017 election, it became clear that Anies displays the opportunistic criterion Weyland ascribes to populists. He took some electoral incentives from the Al-Maida case and the robust movement caused by it (Muhtadi 2019, 98), by choosing to ride on the growing tension and segregation instead of trying to curb the anger of Muslim conservatives. This behavior matches perfectly with the opportunistic character of a populist leader. In this case, the actor, Anies Baswedan who was once labeled as a "moderate Moslem" figure, ${ }^{2}$ could flexibly implement other strategies, different from his moderate ideological commitment, in order to win the election. In other words, Anies can be labeled as a representative or even prototype of his supporters, making him an identity entrepreneur. Thus, the 2017 case shows how political actors were able to interpret the context/strategic environment and did exactly what the strategic environment expected them to do. It can be summarized that populism in the sense of political strategy did occur in Jakarta's gubernatorial election.

The success and the solid basis for using Islamic movements as vote-gathering tools then became a very tempting fruit in the 2019 election. The existing movement and increasing relevance of Islamic values became the strategic environment that should be accepted and utilized. ${ }^{3}$ The anti-Ahok sentiment gradually transformed to anti-Jokowi/incumbent government. ${ }^{4}$ This is unsurprising because Ahok has always been affiliated with the incumbent government or Jokowi's associate. ${ }^{5}$ The opposition then clearly capitalized on the strategic environment in which it benefited them to use Islamic movements, values, and identity as instruments to face Jokowi in the upcoming election. This is evident because since the 2017 election, the parties' coalition had no real changes among its members. The coalition that later opposed Ahok such as Gerindra-Prabowo's political party-and PKS-a relatively right-wing Islamic political party_came back with the same values and spirits of 2017.

\section{Prabowo Subianto's Populist Strategy and Jokowi's Response in the 2019 Presidential Election}

Having lost in the 2014 presidential election, Prabowo needed to come up with a set of strategies to have another run-off with his previous rival, Joko Widodo, the 
incumbent. The 2019 election was the most evident case where Prabowo enhanced his use of Islamic rhetoric to appeal to Indonesian conservatives. This enhancement is consequential to Jakarta's 2017 election when religious rhetoric was strong. One example is in the modification of his campaign rallies that now included passionate chanting of prayers (Ramadhani 2019). Furthermore, Prabowo's intimacy with conservative Islamic movements such as Front Pembela Islam was noteworthy for the involvement of Rizieq Shihab in his campaign. As a leader of FPI, Rizieq Shihab participated in Prabowo's campaign, addressing Prabowo's audience in his campaign rallies via video as he was forced into exile after a pornography scandal. In his videos, Rizieq presented sectarian messages such as urging his followers to choose Prabowo, for Jokowi and his party PDI-P were anti-Islam and crypto-Communist (Warburton 2019). In 2019, Prabowo was still addressing inequality issues but the use of religious issues became more substantial. Social media accounts (especially those that represent themselves as Islamic or Dakwah accounts) that supported or sympathized with Prabowo massively showed videos that satirized Jokowi. ${ }^{6}$ The content varied between different issues such as the critics about the dismissal of HTI or the criminalization of Rizieq Shihab. These were all used to frame Jokowi as somewhat anti-Islam which managed to create an antagonizing constituent group among Muslim conservatives. Thus, we can see the apparent "othering" narratives in which Jokowi was framed as the "elite" (ruling party) or "other" that has an anti-Islam tendency.

Prabowo's enhancement of Islamic narratives in his campaign can be considered strategic. At first glance, Prabowo successfully labeled himself as a figure with special connections to Islamic figures such as Amien Rais or Rizieq Shihab. There were pamphlets and posters everywhere that showed Prabowo and Sandi photographed standing along Rizieq Shihab. ${ }^{7}$ However, a closer look at his track record shows that Prabowo is actually more of a "moderate" who comes from a very diverse family. ${ }^{8}$ Prabowo Subianto is a retired military general with a long history in Indonesian politics as a result of being a prominent figure during Suharto's regime. Also, ultimately, Prabowo had been strategically consistent in addressing inequality in his election campaigns from 2009 to 2014 . Nevertheless, his strategy changed almost drastically in a strategic sense to use religious issues as a political instrument in 2019. This shows the flexibility and the opportunistic character of the leader to capitalize the strategic environment: The strategy of using religious issues was seen as a viable choice as a result of realizing the potential of Islamic movements after they gained their peak momentum and spotlight in the 2017 Jakarta gubernatorial election. Prabowo had also been showing an "othering" tendency ever since his first ambitions to secure the presidential seat, either by talking about the corrupted elite versus lowmiddle class in his early campaigns in 2009-2014 or by antagonizing Muslim conservatives versus Kafir (heathens) in the latest 2019 election. Hence the populist label applies to Prabowo's campaigns.

As a politician who used populism as a political strategy, Prabowo had also benefited in terms of the availability of resources that were needed to implement his desired strategy. He, more or less, has sufficient capital power coming from his businesses. ${ }^{9}$ Moreover, his vice-presidential candidate, Sandiaga Uno, is also a businessman. Prabowo surely displays personal charisma, as shown by his electability 
throughout 2009-2019 ${ }^{10}$ and his party, Gerindra, is one of the biggest parties in Indonesia. As a renowned figure in Indonesian politics, his experience gives him the ability to interpret the context/strategic environment. This can be seen in how he successfully gathered support from some popular Islamic figures such as Rizieq Shihab. ${ }^{11}$ To some extent, those Islamic figures create a body of support through actions such as Itjima Ulama that stated a clear support for Prabowo.

How, then, does Prabowo use his resources to gather the support from these popular Islamic figures and their followers? This is where identity entrepreneurship comes in. The fact that he has succeeded in labeling himself a Muslim figure can be understood as a result of his efforts to become an embodiment of the prototypical leader of existing Islamic identity. Identity entrepreneurs create rhetoric, performances, and discourse based on the issue of social identity in order to create proximity to the voters. The rhetoric is often emphasized by the in-group favoring promises by the identity entrepreneur. This could be seen in some of Prabowo's promises such as the promise to bring back Rizieq Shahib to Indonesia if he were elected president. ${ }^{12}$ This promise clearly matches the notion of identity entrepreneurship that identity entrepreneurs will try to create an inclusive category which includes the people he wants to mobilize.

Thus, the change in Prabowo's and his associates' strategy, compared to his background, track record, and past strategy clearly depicts a high degree of flexibility, just like populist leaders usually exhibit. He also successfully transformed the unorganized followers, in the form of Islamic movements, into broad mass support toward his campaign. In other words, the agency successfully identifies the structure or its strategic environment and then capitalizes it into power in the form of mass support. Ultimately, the agency, Prabowo's side in the election, used what was the "popular" context in society that is the Islamic values and movements, as a legacy of the success of the 2017 election. Thus, it can be argued that populist strategy has been used by the opposition side in the 2019 election.

Prabowo's populist strategy, that to some extent had managed to mobilize significant masses, has pushed Jokowi to shift from his previous pluralist approach to cater to Muslim audiences. At first, Jokowi rose to fame after being the capital's governor in 2012 and his later candidacy for president in the 2014 election was a breath of fresh air to Indonesian primordial and dynastic politics. Due to his down-to-earth image as a humble former mayor and a capable technocrat, Jokowi was depicted as a polite, non-confrontational politician that was essentially more democratic than his opponent. These depictions were important to society that rather enjoyed the benefits of participatory rights in politics as the result of the Indonesian development of democracy (Mietzner 2015). Having put the spotlight on these inclusive and general agendas of development, the 2014 presidential election had allowed Jokowi to be depicted as a favorable pluralist, proven by solid and massive support coming from non-Islamic voters. Nevertheless, Jokowi's choice at that time could be seen as a populist strategy. He tended to label himself as part of ordinary people and stated in his campaign he would not be bound to the "elites" if he got elected (Mietzner 2020, 8). His down-to-earth persona also strengthened his image as part of the non-elite population. Despite some "deficiency" in his campaign conducts (Muhtadi 2019, 80), in which he lost in key conservative Muslim provinces, his strategy had been successful to secure the presidential seat at that time. 
In this case, the Al-Maida scandal, which resulted in the 212 rallies amid the 2017 gubernatorial election and imprisonment of his former partner Ahok, has undeniably changed the course for Jokowi's pluralist approach. This is a vital development in Indonesian politics that strengthened the position of conservative Islamic discourse which skyrocketed the popularity of their speakers such as Rizieq Shihab and Amien Rais. Consequently, Jokowi eventually had to face the rise of the 212 group that utilizes religious-populist discourse. As the ruling regime, Jokowi was then framed as part of the "elites" and a new discourse was built that Jokowi's regime was somewhat similar to the authoritarian regime of Suharto, thus increasing the notion of Jokowi's government as the "elites" (Saputra 2019; Fadil 2019). Moreover, the "communist" rumors were brought back to the surface along with the anti-Islam label (Carina 2019). Thus, he was in a very vulnerable position for populist attacks of his rivals.

The mobilization of identity by Prabowo Subianto was definitely threatening the incumbent's side. Thus, Jokowi had to take a breakthrough approach to secure his chance in the 2019 presidential election amid the strategic environment that tended to favor his challenger. Facing this condition, Jokowi saw the need to have programs that can accommodate his weakest electoral markets, the Islamic population. Hence the programs such as pesantren (Islamic boarding school) revitalization and regulation reforms to ummah-centric economy were introduced by Jokowi near the election months (IPAC Report 2019, 15). Jokowi maintained his technocratic approach through the campaign theme of "Indonesia Optimis" (literally translated into Optimistic Indonesia), a campaign rhetoric based on the idea of optimism and his track record as president, especially the programs and large infrastructure projects he had already completed. Leading up to the campaign, Jokowi's social media accounts regularly featured images of Jokowi visiting major projects, including bridges, major highways, and, most famously, Jakarta's new mass rapid transit system (Hatherell and Welsh 2019, 11).

Jokowi also responded to the challenge by mixing his technocratic approach with religious discourse. This is evident in his strategy to finally use the religious card, distancing himself from possible criticism of him being secular. Having lost in key conservative regions in 2014, Jokowi tried to amend his relationship with these conservatives starting from his choice for vice-president, Ma'aruf Amin as the strongest leader in Nahdatul Ulama that is one of the most prominent Islamic movements in Indonesia, for establishing an ummah-centric economy and heavily invested on pesantrens in Indonesia. This goal was translated into his newly published Economic Equality Policy, the establishment of the official National Day of Islamic Youth (Hari Santri) in the national calendar, which celebrates the Muslim students of Indonesia, and the formation of the Sharia Economic Committee-a policy making committee on the basis of Islamic law-by the end of his first presidential term (IPAC Report 2019, 11). Furthermore, Jokowi was also seen to appear in public with white-dominated Islamic attire instead of a suit or his formerly trending checkered (kotak-kotak) shirt, to construct the image of a favorable pious Islamic figure. These actions were conducted strategically amid his incumbency, specifically during the momentum of his re-election campaign rallies (Hatherell and Welsh 2019, 11).

The shift to appeal to Muslim moderates is seen as a strategic move, as Jokowi had faced tremendous pressure from the conservatives that constantly questioned his 
piousness (Aspinall and Mietzner 2019). However, his approach to Ma'aruf Amin as one of the prominent symbols of conservative Muslims also has its own implication toward his traditional pluralist voter base. Considering his rise to fame as the governor of DKI Jakarta with Ahok in 2012 was undeniably due to massive pluralist support from millennials, Jokowi also needed to maintain this support base. In the 2017 strategic environment that lasted until the political momentum in 2019, the power of conservative Muslims had surged and thus was seen to be a threat to religious pluralism in Indonesia (Aspinall and Mietzner 2019). Accommodating moderate Muslims was considered to be the most reasonable way in serving the interests of Muslim voters and those from the pluralist base.

Jokowi tried to maintain his down-to-earth image to present himself as a part of ordinary people rather than elites. It can be observed that in a number of presidential debates, he answered with a technocratic approach, such as how to accelerate the bureaucratic service and improve digital technology (Ihsanuddin 2019). Nevertheless, although Jokowi did not state that many problems were caused by the predatory elite, in November 2018 he stated that there are some super rich that never go to local markets but claiming that the prices in local markets are skyrocketing (Agiesta 2018). Some writers such as Mietzner argue, in the context of populism, that this statement is an attack on Prabowo's partner, Sandiaga Uno, in order to create an image that Jokowi was part of ordinary people and knew their struggle that the elites had no understanding about (Mietzner 2020, 8-9).

Jokowi's strategy can also be seen as a response to Prabowo's intimacy with Muslim conservatives, as he was repeatedly endorsed by the 212 movement, one of the largest scale public protests that advocated for a conservative turn for Indonesian Muslims. This alliance was seen as a threat to Indonesian pluralism. Jokowi then tried to sweep in as the anti-thesis of this conservative approach, as an effort to secure his victory in the 2019 election. As the campaign for abstention had its momentum for a while, pluralist leaders and government agencies used Prabowo's conservative image to remind the voters that abstaining would lead to Prabowo's victory. The campaign seemed to work as the turnout went from $70 \%$ in 2014 to $79 \%$ in 2019 (Aspinall and Mietzner 2019, 114) indicating that pluralist voters chose Jokowi in the voting booth to keep conservatives away from the executive governing body of Indonesia.

Conclusively, adding a religious dimension to Jokowi's campaign was seen as a necessary strategy to secure votes to win the 2019 presidential election. The mixed approach indicates the flexibility and Jokowi's ability to interpret and survive in the political strategic environment in 2019. Notably, this behavior was to some extent "encouraged" as a response toward Prabowo's use of populism that appeals to Indonesian Muslim conservatives. Therefore, it could be said that Jokowi also uses populist strategy, although the intensity, especially in the use of religious narratives, is lower than his rival's (Mietzner 2020, 8-10). Furthermore, having seen the result that still favored Jokowi, it was visible that in the case of Indonesia, the robust use of religious narratives does not guarantee victory in electoral contestation.

It became more interesting when Prabowo then joined Jokowi's cabinet as Minister of Defense (Gorbiano 2019). Lately, Sandiaga Uno is also appointed as the Minister of Tourism and Creative Economy (CNN Indonesia 2020). These developments, 
however, cannot be interpreted as the end of the "us vs. them" in Indonesian politics. In fact, religious identity continues to be nurtured by some of its holders. They have been trying to maintain the sparks through occasional events and statements (Ihsanuddin 2020). It will be interesting to observe whether Prabowo or other political leaders will re-embrace religious identity in the next 2024 election.

\section{Conclusion}

The development of Indonesian politics in the last few decades shows that populism has been used in vote-gathering strategies. Identity and primordial approaches, especially the religious one, are solidifying their effects in the search for effective mass mobilization in electoral strategies. The mixture between Pancasila and Islam is a form of this strategy since Islam could not be a dominant political discourse by itself. In other words, the Islamic discourse must adapt with the fact that Pancasila is still the dominant ideology in Indonesia. Considering political strategies to mobilize masses and voters heavily revolved around the identity dimension, we can see that the battle in elections includes the process of reconciling Islamic identity with the values of Pancasila. The mobilization of identity thus rises to meet this need.

This paper argues that populism as a strategy was used in the 2019 Indonesian presidential election. There is evidence of "othering" narratives that create a dichotomy of "us vs. them." We can also see the opportunistic and flexible characteristics of the actors involved in the recent election. All of these heavily depend on the strategic electoral market at the given time. The initiative to mobilize Islamic identity started to surface in the 2014 election. Prabowo Subianto had not used Islamic identity as his main weapon but combined Islamic identity with his more dominant appearance as a nationalistic figure. Prabowo mainly used the nationalistic rhetoric and performance to target his audiences, especially those who missed strong and charismatic leadership. On the contrary, Jokowi portrayed himself more as a humble, down-to-earth man, with youthful and fresh looks to relate to younger voters. The religious identity issues became stronger in the months before election day as a way to halt the skyrocketing popularity of Jokowi. This trend then erupted robustly in the case of Jakarta's 2017 election, creating a solid strategic environment to use religious notions as instruments to gather votes in 2019. The 2019 presidential election then marked a much more robust use of identity as a mass mobilization instrument and saw the rise of Islamic conservatism in national political discourse. This condition forced the candidates to take their attention toward this new development of the electoral markets.

The strategic environment that favors the use of the then "popular" religious values has been capitalized by Prabowo. As a result, Prabowo has been successfully presented himself as a Muslim figure. This reflects the assumption that a populist leader usually has flexible characteristics since Prabowo was not originally a Muslim figure. It is clear that Prabowo's side has been successful in capitalizing on the existing strategic environment by using religion-based populism as an instrument to gather more votes in the 2019 election. Inevitably, this pushed Jokowi's side to react by catering to the more moderate Islamic population. Jokowi sought to defend this electoral base by adding some identity dimensions in his program-based campaign to "catch up" with their counterpart that had implemented a populist strategy. 
The fact that both presidential candidates used the identity approach to respond to the contemporary development in their environment and electoral markets underlines that the "identity card" will still be an important and determining instrument to survive in Indonesian politics. Interestingly, it should be noted that the rise of conservatism in Indonesian society does not automatically require the political actors in Indonesia to fully accommodate or side with the conservative party. Political actors in Indonesia should be aware that the Islamic population in Indonesia consists of many movements that often conflict with each other. This means, in dealing with this pluralist society, identity entrepreneurs should target and define their specific electoral markets and find the right expressions to win their trust.

The uses of identity as a strategy in responding to the strategic environment in Indonesian politics mean that the repertoires of political strategies in post-Reformation Indonesia are still leaning toward populist methods. The deeprooted influence of primordialism, populism, and identity politics along with the arguably limited deliberations of democratic principles provide a perfect "strategic environment" in which identity users shall find their significant roles in linking the leaders with the masses and voters. Religious identity, thus, was mostly favored in the 2019 presidential election as an element of populism that signified political movements that are closely related to power competition and vote-gathering behavior. Hence, it can be argued that what exists in Indonesia's current political arena is a considerably flexible populism which uses religious identity as a determining factor in a considerably dynamic political context.

\section{Notes}

1. Blusukan is a Javanese term to describe the act of a leader who meets his/her constituents directly in their spaces such as traditional markets, Islamic boarding schools (pesantren), pedestrian zones, villages, etc.

2. Before the Jakarta gubernatorial election, Anies Baswedan was often mentioned as an influential intellectual and a moderate Muslim. Foresight Magazine included Anies Baswedan as a moderate Muslim. This was then covered by many local newspapers (“Anies Baswedan Tokoh Dunia Berpengaruh,” in Kompas. com, May 1, 2020, https://edukasi.kompas.com/read/2010/05/01/03195943/anies.baswedan.tokoh.dunia. berpengaruh?page=all). Foreign Policy Magazine also included Anies as an influential intellectual (see: “The Top 100 Public Intellectuals: Bios," Foreign Policy, April 19, 2008; https://foreignpolicy.com/2008/ 04/19/the-top-100-public-intellectuals-bios).

3. This trend could be seen in the form of, for example, various religious leaders in social media that promote a more fundamental Islamic point of view on politics. See Nursita Sari, "Penjelasan Felix Siauw soal Ceramahnya di Balai Kota DKI," Kompas, June 26, 2019 (https://megapolitan.kompas.com/read/2019/06/ 26/16392431/penjelasan-felix-siauw-soal-ceramahnya-di-balai-kota-dki).

4. After successfully displaying a great impact in Ahok's blasphemy case, the 212 movement shifted to a narrative that PDIP and Jokowi were both corrupted and anti-NKRI, anti-Bhinneka and drew on other forms of fear concerning Islam and existential threats in their grassroots movements (see more on "Prabowo sebut 'tidak boleh kampanye' di Reuni 212, Rizieq serukan 2019 ganti presiden," $B B C$ Indonesia, December 2, 2018; https://www.bbc.com/indonesia/indonesia-46416341).

5. Ahok first gained popularity when he took office with Jokowi as governor and vice-governor of Jakarta in 2012. He showed great support for Jokowi's presidency which led him to become the governor of Jakarta. As the governor of the capital, he was always portrayed as Jokowi's close ally (see Marcus Mietzner, "How Jokowi Won and Democracy Survived," Journal of Democracy Vol. 25, No. 4 (October 2014); https://www. journalofdemocracy.org/wp-content/uploads/2014/10/Mietzner-25-4.pdf).

6. There are some discussions and issues that Jokowi represents anti-Islamic politics. Hoaxes that were often heard during his campaign period were the criminalization of Ulama, the prohibition of adzan, 
legalization of homosexual marriage and the elimination of religious ministries (see more in Sandro Gatra, "Jokowi merasa diserang 4 fitnah jelang Pemilu," Kompas.com, 3 Maret 2019; https://nasional.kompas.com/ $\mathrm{read} / 2019 / 03 / 09 / 16475681 /$ jokowi-merasa-diserang-4-fitnah-jelang-pemilu). This is not new, considering Jokowi had been attacked repeatedly for being secular since his first term as president-that correlates with how he prioritized technocratic narratives rather than the ideological one (Marcus Mietzner, "How Jokowi Won and Democracy Survived," Journal of Democracy Vol. 25, No. 4 (October 2014); https:// www.journalofdemocracy.org/wp-content/uploads/2014/10/Mietzner-25-4.pdf).

7. Interestingly, some of the photographs showed Prabowo smaller in size than Rizieq in the very same picture. For example, see Azis Anwar Fachrudin, "Questioning Prabowo's Alliance with Islamists," New Mandala, March 15, 2019 (https://www.newmandala.org/questioning-prabowos-alliance-with-islamists/).

8. Some of his family members are non-Muslim, which was highlighted when a video showed Prabowo and his family having Christmas celebrations in December 2018 (see more on "Anti-Ahok to Anti-Jokowi: Islamist Influence on Indonesia's 2019 Election Campaign,” IPAC Report no. 55, March 2019).

9. Prabowo relies on his brother Hashim Djojohadikusumo who is one of the richest people in Indonesia to back him up. Also considering that Prabowo used to be one of the closest confidants of Suharto, he has access to investment in Indonesia's essential resources such as coal mining, fisheries, palm oil, timber, pulp, and paper. Ever since his political ambitions got more serious, his wealth has multiplied by a factor of 160 from $\$ 840,000$ in 2003 to $\$ 135$ million in 2009 and \$143 million in 2014 (see more on Edward Aspinall, "Oligarchic Populism: Prabowo Subianto's Challenge to Indonesian Democracy," Indonesia no. 99 (April 2015), pp. 1-28).

10. In 2009 and during his first appearance in a presidential election, Prabowo teamed up with Megawati Sukarnoputri as her candidate for vice-president and managed to gain $26.79 \%$ of votes. In 2014, however, he stepped up to the election for president, with Hatta Rajasa as his vice-president and got $46.85 \%$. Finally, in the latest 2019 presidential election for which he teamed up with Sandiaga Uno got him $44.50 \%$ of votes. ("SBY-Boediono Menang 60,80 Persen," kompas.com, July 23, 2009 https://nasional.kompas.com/read/2009/07/23/18004364/SBY-Boediono.Menang.60.80.\%20Persen; "Ini Hasil Resmi Rekapitulasi Suara Pilpres 2014," kompas.com, July 22, 2014, https://nasional.kompas.com/read/2014/07/22/20574751/ Ini.Hasil.Resmi.Rekapitulasi.Suara.Pilpres.2014?page=all; and "Hasil Pilpres 2019: Jokowi-Ma'ruf 55,50 Persen, Prabowo-Sandi 44,50 Persen, Selisih 16,9 Juta Suara," kompas.com, May 21, 2019, https://nasional. kompas.com/read/2019/05/21/02440251/hasil-pilpres-2019-jokowi-maruf-5550-persen-prabowo-sandi-4450persen.

11. The conservative Ulamas who backed Prabowo announced three Ijtima Ulama; each of them promoted support explicitly for Prabowo. The first one was to recommend the vice-president for Prabowo, Ustadz Abdul Somad-which was not followed by Prabowo. The second one was to sign the Integrity Pact to secure the Ulamas support, and finally the third one was used to delegitimize the election result and recommend for the legal process to start (Dewi Nurita "Ijtima Ulama GNPF Rekomendasikan Abdul Somad Cawapres Prabowo" tempo.co, July 29, 2018 https://nasional.tempo.co/read/1111556/ijtima-ulama-gnpf-rekomendasikan-abdul-somad-cawapres-prabowo; Ramadhan Rizki "Arah Ijtima Ulama II, Antara Ogah Jokowi dan Legitimasi Sandi” CNN Indonesia.com August 14, 2018 https://www.cnnindonesia.com/nasional/ 20180814183051-32-322259/arah-ijtima-ulama-ii-antara-ogah-jokowi-dan-legitimasi-sandi; and "Ijtima Ulama 3 minta KPU 'diskualifikasi Joko Widodo-Ma'ruf Amin', dalam acara yang disebut pengamat mendelegitimasi KPU” BBC.com May 1, 2019 https://www.bbc.com/indonesia/indonesia-48115869).

12. This discourse is fully supported by FPI and several Muslim leaders. See: Merdeka, "Teken pakta integritas, Prabowo janji pulangkan Habib Rizieq," Merdeka.com, September 16, 2018 (https://www.merdeka. com/politik/teken-pakta-integritas-prabowo-janji-pulangkan-habib-rizieq.html).

\section{References}

Agiesta, Fellyanda Suci. 2018. “Siapa Orang Super Kaya yang Disindir Jokowi?” Merdeka.com. November 27. https://www.merdeka.com/politik/siapa-orang-super-kaya-yang-disindir-jokowi.html (Accessed November 27, 2020).

Agung, Bintoro. 2018. "Mardani Akui Manfaatkan Aksi 212 untuk Menangkan Anies-Sandi." CNN. July 12. https://www.cnnindonesia.com/nasional/20180712200852-32-313676/mardani-akui-manfaatkanaksi-212-untuk-menangkan-anies-sandi (Accessed July 12, 2020). 
Alamsyah, Andi Rahman, and Vedi R. Hadiz. 2017. "Three Islamist Generations, one Islamic State: The Darul Islam Movement and Indonesian Social Transformation." Critical Asian Studies 49(1):54-72.

“Anti-Ahok to Anti-Jokowi: Islamist Influence on Indonesia's 2019 Election Campaign." 2019. IPAC Report No. 55.

Aspinall, Edward. 2014a. "Indonesian Politics in 2014: Democracy's Close Call." Bulletin of Indonesian Economic Studies 50(3):347-369.

Aspinall, Edward. 2014b. "Prabowo dan Bahaya Terhadap Demokrasi Indonesia." IndoPROGRESS, July 3. https://indoprogress.com/2014/07/prabowo-dan-bahaya-terhadap-demokrasi-indonesia/ (Accessed July 3, 2020).

Aspinall, Edward. 2015. "Oligarchic Populism: Prabowo Subianto's Challenge to Indonesian Democracy," Indonesia 99 (April 2015), 1-28.

Aspinall, Edward, and Marcus Mietzner. 2019. "Southeast Asia's Troubling Elections: Nondemocratic Pluralism in Indonesia." Journal of Democracy 30(4):104-118.

Carina, Jessi. 2019. "Pilpres 2019 dan Isu PKI yang Mengusik Jokowi..." Kompas. June 30. https://nasional. kompas.com/read/2019/06/30/09413151/pilpres-2019-dan-isu-pki-yang-mengusik-jokowi?page=all (Accessed May 30, 2020).

de Marques, Sales Jose Luis (ed). 2019. Cultures, Nationalism and Populism New Challenges to Multilateralism. London: Routledge.

Fachrudin, Azis Anwar. 2019. "Questioning Prabowo's Alliance with Islamists." New Mandala. March 15. https://www.newmandala.org/questioning-prabowos-alliance-with-islamists/ (Accessed March 15, 2021).

Fadil, Vicky. 2019. "Panik, Rezim Jokowi Mirip Order Baru!!!.” Warta Ekonomi. September 27. https:// www.wartaekonomi.co.id/read248785/panik-rezim-jokowi-panik-mirip-orde-baru.html (Accessed September 27, 2020).

Fossati, Diego. 2019. "Analyzing Indonesia's Populist Electorate: Demographic, Ideological, and Attitudinal Trends." Asian Survey 59(5):769-794.

Gorbiano, Marchio Irfan. 2019. "He knows more than I do': Jokowi picks Prabowo as defense minister." The Jakarta Post. October 23. https://www.thejakartapost.com/news/2019/10/23/he-knows-more-than-ido-jokowi-picks-prabowo-as-defense-minister.html (Accessed October 2, 2020).

Hadiz, Vedi R. 2004. "The Failure of State Ideology in Indonesia: The Rise and Demise of Pancasila." In Communitarian Politics in Asia, ed. Chua Beng Huat, London: Routledge Curzon, 148-161.

Hadiz, V. 2016. Islamic Populism in Indonesia and the Middle East. Cambridge: Cambridge University Press.

Hadiz, V., and R. Robison. 2017. "Competing Populisms in Post-Authoritarian Indonesia." International Political Science Review 38(4):488-502.

Haslam, S. Alexander. 2007. "Identity Entrepreneurship and the Consequences of Identity Failure: The Dynamics of Leadership in the BBC Prison Study." Social Psychology Quarterly 70(2):125-147.

Hatherell, Michael, and Alistair Welsh. 2019. "Populism and the Risks of Conceptual Overreach: A Case Study from Indonesia." Representation: Journal of Representative Democracy 56(1):53-69.

Helmann, Olli. 2011. Political Parties and Electoral Strategy: The Development of Party Organization in East Asia. Basingstoke: Palgrave Macmillan.

Ihsanuddin. 2019. “Jokowi Tanya Prabowo Soal 'Mobile Legend' dalam Debat Pilpres." Kompas.com. April 13. https://nasional.kompas.com/read/2019/04/13/22003371/jokowi-tanya-prabowo-soal-mobile-legenddalam-debat-pilpres (Accessed April 13, 2020).

Ihsanuddin, 2020. “Tiba di Markas FPI, Rizieq Sampaikan Pidato di Depan Simpatisannya." Kompas.com. October 10. https://megapolitan.kompas.com/read/2020/11/10/14165701/tiba-di-markas-fpi-rizieq-sampaikan-pidato-di-depan-simpatisannya (Accessed December 10, 2020).

“Jokowi Resmi Tunjuk Sandiaga Uno Jadi Menteri Parekraf." 2020. CNN Indonesia. December 22. https://www.cnnindonesia.com/ekonomi/20201222102011-532-585069/jokowi-resmi-tunjuk-sandiaga-unojadi-menteri-parekraf (Accessed January 11, 2021).

Kumparan 2019. "Rizieq minta FPI perjuangkan NKRI Bersyariah: Roh Pancasila." Kumparan, August 21. https://kumparan.com/kumparannews/rizieq-minta-fpi-perjuangkan-nkri-bersyariah-roh-pancasila1rjAvGz7qsH (Accessed November 21, 2020).

Kyle, Jordan, and Limor Gultchin. 2018. "Populists in Power Around the World." Tony Blair Institute for Global Change. https://institute.global/sites/default/files/articles/Populists-in-Power-Around-the-World-. pdf. 
Madinier, Rémy. 2015. Islam and Politics in Indonesia: The Masyumi Party between Democracy and Integralism. Singapore: NUS Press.

Mietzner, Marcus. 2014. "How Jokowi Won and Democracy Survive." Journal of Democracy 25(4):111-125.

Mietzner, Marcus. 2015. "Reinventing Asian Populism: Jokowi's rise, democracy and political contestation in Indonesia.” Policy Studies 72. Hawaii: East-West Center.

Mietzner, Marcus. 2020. "Rival Populisms and the Democratic Crisis in Indonesia: Chauvinists, Islamists and Technocrats." Australian Journal of International Affairs 74(4):420-438.

Mudde, C. 2004. "The Populist Zeitgeist." Government and Opposition 39(4):541-563.

Mufrodi, Ali. 2017. “The Rivalry of Ahok versus Anies in Jakarta Election 2017." In Proceedings of the International Conference on Muslim Society and Thought, Surabaya.

Muhtadi, Burhanuddin. 2019. Populisme Politik Identitas \& Dinamika Elektoral. Malang: Intrans Publishing.

Neuman, W. Lawrence. 2003. Social Research Methods: Qualitative And Quantitative Approaches Fifth Edition. New York: Pearson.

Ostwald, Kai, et al. 2018. "Rematch: Islamic Politics, Mobilization and the Indonesian Presidential Election." Political Science 70(3):240-252.

Oxhorn, P. 1998. “The Social Foundations of Latin America's Recurrent Populism: Problems of Popular Sector Class Formation and Collective Action." Journal of Historical Sociology 11(2):212-246.

Ramadhani, Nurul Fitri. 2019 “SBY questions Prabowo's campaign event, calling it too 'exclusive'." The Jakarta Post. April 7. https://www.thejakartapost.com/news/2019/04/07/sby-questions-prabowos-campaign-event-calling-it-too-exclusive.html (Accessed August 8, 2020).

Reicher, Stephen, and S. Alexander Haslam. 2017. "The Politics of Hope: Donald Trump as an Entrepreneur of Identity." In Why Irrational Politics Appeals: Understanding Why Trump Allure, ed. Mari Fitzduff, California: Praeger Publisher, 25-40.

Reicher, Stephen, Nick Hopkins, Mark Levine, and Rakshi Rath. 2005. "Entrepreneurs of Hate and Entrepreneurs of Solidarity: Social Identity as A Basis for Mass Communication." International Review of the Red Cross 87(860):621-637.

Ristianto, Christoforus. 2019. "Survei Indikator Tunjukkan Perubahan Suara Pemilih Islam dari Prabowo ke Jokowi.” Kompas. April 3. https://nasional.kompas.com/read/2019/04/03/23400571/survei-indikatortunjukkan-perubahan-suara-pemilih-islam-dari-prabowo-ke (Accessed July 2, 2020).

Saputra, Andi. 2019. "Prabowo Sebut Jokowi Neo-Orde Baru, Ahli Hukum: Gugatan Pilpres Terburuk." Detik.com. May 31. https://news.detik.com/berita/d-4572238/prabowo-sebut-jokowi-neo-orde-baruahli-hukum-gugatan-pilpres-terburuk (Accessed September 30, 2020).

Sari, Nursita. 2019. “Penjelasan Felix Siauw soal Ceramahnya di Balai Kota DKI.” Kompas. June 26. https:// megapolitan.kompas.com/read/2019/06/26/16392431/penjelasan-felix-siauw-soal-ceramahnya-di-balaikota-dki (Accessed September 26, 2020).

Setijadi, Charlotte. 2017. “Ahok's Downfall and the Rise of Islamist Populism in Indonesia.” ISEAS Perspective Issue 2017, No. 38.

Stanley, B. 2018. “The Thin Ideology of Populism.” Journal of Political Ideologies 13(1):95-11.

Tomsa, Dirk. 2018. "Parties and party politics in the Post-Reformasi era," in Routledge Handbook of Contemporary Indonesia (ed. by Robert W. Hefner). New York: Routledge, 95-105.

Warburton, Eve. 2019. "Polarisation in Indonesia: What if perception is reality?" New Mandala. April 16. https://www.newmandala.org/how-polarised-is-indonesia/ (Accessed February 16, 2020).

Warburton, Eve, and Edward Aspinall. 2019. "Explaining Indonesia's Democratic Regression: Structure, Agency and Popular Opinion." Contemporary Southeast Asia 41(2):255-285.

Weyland, K. 2001. "Clarifying a Contested Concept: Populism in the Study of Latin American Politics." Comparative Politics 34(1):1-22.

Weyland, K. 2017. "Populism. A Political-Strategic Approach." In Oxford Handbook of Populism, eds. Cristóbal Rovira Kaltwasser, Paul A. Taggart, Paulina Ochoa Espejo and Pierre Ostiguy. Oxford: Oxford University Press, 48-72.

Zarkasyi, Hamid Fahmy. 2008. "The Rise of Islamic Religious-Political Movements in Indonesia: The Background, Present Situation and Future." Journal of Indonesian Islam 2(2):336-378.

Ziv, Daniel. 2001. "Populist Perception and Perception of Populism in Indonesia: The Case of Megawati Sukarnoputri." South East Asia Research 9(1):73-88. 
Rizky Widian is a lecturer in the International Relations Department, Parahyangan Catholic University, with research interests in Indonesian politics, Southeast Asia region, and security issues.

Putu Agung Nara Indra Prima Satya is a lecturer in the International Relations Department, Parahyangan Catholic University, with research interests in identity politics, U.S. global politics, peace and conflict resolution, and identity-based conflict.

Sylvia Yazid is an Associate Professor in the International Relations Department, Parahyangan Catholic University, with research interests in democratization, human rights, and migration.

Cite this article: Widian R, Satya PANIP, Yazid S (2022). Religion in Indonesia's Elections: An Implementation of a Populist Strategy?. Politics and Religion 1-23. https://doi.org/10.1017/ S1755048321000195 